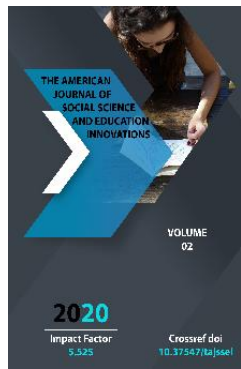

\section{D.N. Logofet-Surkhan Oasis Researcher}

\author{
Eshbolta Kobulov \\ Doctor Of Historical Sciences Of Termez State University, Uzbekistan \\ Begalieva Mehriniso Olimnazarovna \\ Lecturer Of The Department Of History And Source Studies Of Uzbekistan
}

Copyright: Original content from this work may be used under the terms of the creative commons attributes 4.0 licence.

\title{
ABSTRACT
}

This article presents valuable information about the Bukhara Emirate, especially the eastern part of Emirate, the history, archeology, ethnography, and agriculture and trade system of the Surkhandarya oasis during the travels of the famous Russian orientalist, military figure D.N Logofet to Central Asia in this article.

\section{KEYWORDS}

The Bukhara Emirate, EasternBukhara, Surkhan oasis, Denau,Gissar, colonialism, strategy,Kafirnigan, officer, orientalist

\section{INTRODUCTION}

The works of Russian scientists, military officials, tourists and local historians play an important role in the study of the history of Central Asia in the XIX-early XX centuries. They have published many scientific articles, pamphlets and books on the history, geography, ethnography and other areas of the country. This scientific research, no matter how it is written, serves as an important resource today. Researchers working in the field of history, in order to critically study the above-mentioned works, include in the scientific coverage of materials related to the history of our country. 
It is known from history that the Surkhandarya oasis, which is of great strategic importance, has always been in the center of attention of the rulers and sent many researchers to study the country. The works of military officer D.N. Logofet are of special importance in the study of the history of the Surkhandarya oasis during the colonial period of the Russian Empire. D.N. Logofet was born on March 12, 1865 in the village of Gurevka, Eltsky district, Orel region, Russia. He devoted his entire life to military service. He was a volunteer at the Faculty of Law of Moscow University. He later completed a course in Oriental languages at the St. Petersburg Institute of Archeology, which hampered his later work in Central Asia. [1, p, 67-74]. His books such as "On the borders of Central Asia: travel essays in 3 books." (St. Petersburg, 1909), "Land of lawlessness". Bukhara khanate and its present state" (St. "(St. Petersburg, 1911)," In the mountains and plains of Bukhara "(St. Petersburg, 1913)," Irrigation of Termez "," Bread trade and stocks of Eastern Bukhara "," In a forgotten country. Travel sketches in Central Asia "," Post and telegraph sites in the Bukhara domains " and many other works play an important role in the study of the history of the region, especially the history of the Eastern Bukhara Emirate. D.N. Logefet's “Land of lawlessness" (1909) has a special place in the study of political and economic life of the Bukhara emirate, including the Surkhandarya oasis in the early twentieth century. During the time of principalities of the oasis became participants in it. The play shows the ethnographic selection of the emirate's population in 8 groups, and the most densely populated areas are the upper reaches of the Surkhandarya River, the area around the Kofirnihon and Kizilsuv rivers. During the period when the Emirate of Bukhara became a vassal of Tsarist Russia, starting from 1888, focusing on the construction of the Termez fortress on the southern border, they created a fourth Russian settlement [2, p, 16]. In this play, he mentions the possibility of large-scale farming on the banks of rivers (Surkhan, Kofirnihon, Amudarya, etc.).

It is noted that it is possible to get a rich harvest through the irrigation systems used in the past and there are large areas of arable land.DN Logofet provides information on the Amudarya and Surkhandarya irrigation systems in Sherabad, Termez, and northern Afghanistan. Yanov and $\mathrm{K}$ were also given large plots of land. The Moscow Stock Exchange Committee has also shown great interest in expanding the cotton fields in Central Asia.An expedition led by G.Minderwas organized to design a special irrigated land. The engineering activity requires special attention to the lands around Bukhara. In particular, the traces of the Amudarya canals open up great opportunities for the irrigation system.

The expedition was tasked with exploring the frontier gray lands of the Bukhara Emirate and developing new cotton plantations. It should be noted that the Amudarya,Rivers such as Surkhan, Vakhsh, Kofirnihon, Panj and Kizilsuv, which give a very large part of the water, can be used to expand cotton fields; [3, p109110].In his works, Logofet also gives specific examples, noting that the inhabitants of the oasis principalities had their own school in grain growing. He noted that the grain grown by the farmers of the region not only met the needs of the population, but also 2,000 pounds in Boysun, 25,000 poods in Denau and 14,000 poods in Sherabad were delivered to the markets of neighboring principalities; [2, p. 47] The play also examines the emirate's annual tax revenue and its principalities. According to the author, the Boysun principality was taxed at 150,000 rubles, Sherabad at 150,000 rubles, and Denau at 200,000 rubles; [2, p. 30]. The role of the Surkhandarya oasis in the trade 
relations of the Emirate of Bukhara with the countries beyond the Amu Darya, in particular, the crossings of Chochkaguzar, Termez, Pattakesar and the fee imposed on it, is studied in detail in the play. It was noted that the construction of the 376 verstTermezSamarkand postal road was mainly built by the local population and was of strategic importance; [4, p 2-3] Part 2 of his book "Bukhara Khanate under the Russian Protectorate" contains a lot of information about the socio-political life of the oasis. The section "Education and Religion" focuses on cultural life and religion in the Bukhara Emirate, and provides information on madrassas in the cities of Denau, Yurchi, Sherabad; [5, p. 7] led to the occurrence of departures in the areas bordering on. There is also valuable information about the rivers of the oasis and their role in the irrigation system. Without carrying out any irrigation works, 1000 sq.m. Verst states that there is land suitable for farming. There is also information about the types of crops and the yields obtained from it. It was during Logofet's research that new types of horticultural crops, including cabbage, cucumbers, potatoes, and garlic, began to be planted around Termez. In this work, the author deeply studies animal husbandry and its role in the economy.

The largest livestock sector is sheep breeding, camel breeding and their ratio per capita. In particular, the number of sheep in the emirate is 3.5 per capita, camels - 1 per 6 people; [2, p. 117] In 1897 the Turkestan Geographical Society was established and D.N. Logofet studied the history and ethnography of the Eastern Bukhara Emirate. His services were awarded the Great Order in 1900,1903, 1907. Thanks to the services of engineer Ananev, this first Russian residence was built for three years as the main military border town of the Emirate of Afghanistan and Bukhara, as well as Surkhan gives information that it is possible to create a very large irrigation system with the help of water, and that Termez, the southern part of the Sherabad principality, should be turned into a huge city on the Russian trade route. In 1898, an engineer Gelman's expedition arrived in Termez. The main task was to draw up an initial project for the irrigation of lands near Termez with a total area of about 4,750 desiatins. Later considered by a number of commissions, and finally in 1899 a special council was convened under the chairmanship of General Dukhovsky, the commander of the army. The Council made the final decision that the Russian government should take over the improvement and expansion of the irrigation systems of all existing Pattakesar and Salihabad canals, along with the construction of a new and reliable canal starting from the Salihabad canal.

\section{RESULTS AND DISCUSSIONS}

As a result of this decision, the relevant application was accepted and the Emir of Bukhara provided the Russian government with 9,000 desiatins of land free of charge.In connection with the transfer of this huge plot of land to the disposal of the Russian government, it was commissioned to consider the project of military engineer Gelman. He had to reconsider the irrigation system of the Termez lands by conducting a new comprehensive study. In 1900, an expedition of engineer Kastalskywas allowed. The entire irrigation system was to be located along the banks of the Surkhandarya River and the Salihobod River on both banks of the Surkhandarya River, $120 \mathrm{~km}$ from Termez. At the same time, the chief dam built by engineer Kastalsky on the Surkhandarya Riveran irrigation project will be constructed through a special ditch with a cooling basin. This was done because the Surkhan water was very 
turbid. In 1901, a project to build a new canal was approved. Irrigation of Termez was a matter of state importance. Because of the favorable conditions, it was possible to create a large trading city here, which would allow the Russian government to conduct trade relations with Afghanistan. The rapid development of the Russian village of Pattakesar near Termez clearly proves that this area creates great trade opportunities. It is necessary to do everything possible to turn Termez into a huge city in the future.At the heart of these opportunities was, of course, an economic benefit irrigation system. To carry out this work, the position of Ilita Irrigation Director and an elder who is well versed in canal work will be established. All costs will be incurred to turn TermezPattakesar into a city with a large population. A number of experts are invited to improve the irrigation system. One of the engineers who carried out such a huge project was a military engineer Ananev [3, p, 125-126]. The territory of Termez is located 6-7 km from Pattakesar. There are many towers here. The perimeter of the towers is covered with colored glazed brick cladding. Near the city of Termez there is Zoyinabad fortress. The largest city on the banks of the Amudarya is Termez. Termez is located on the right road from Samarkand to Mazari Sharif and Kabul. [125-126]

During his trip through the territory of East Bukhara, D.N. Logofet will also provide information about the natural climate of the emirate's towns and villages, the system of domestic and foreign trade. only 14 pounds of grain were put up for sale.In the remaining territories 700-800 poods were collected and sent by the beys to the emirate's center as tribute. Grain sent to the emirate's markets for sale was sold at the emirate's price. In late August, a large caravan of camels arrived from Termez and Kerkon in eastern Bukhara, as well as from Khiva. In the markets of Kulyab and
Boljuvon, a batmon of yachmin cost $25-40$ tenge ( 3 r.75k). Wheat cost 35-40 tenge. Its price was determined depending on the yield. The post of Fayziabad was considered to be the most important. In 1905, a society was opened near the banks of the Amudarya River to receive grain cargoes.20 kop coins were given for each pound during storage and delivery of products to Termez $[7 ; 105-117 \mathrm{~s}]$.

The Orientalist D.N. Logofet also provides information on the ethnography of the cities and topony of the Eastern Bukhara Emirate. He worked on the irrigation system of Termez, as well as on the irrigation system of the Sherabad principality adjacent to Termez. As a result of the military engineers Poslansky, Kastalsky, Ermolev and Anaanev's excellent knowledge of the language and culture of the local population, various great opportunities arose in and around Termez. Later, the Russian government began to consider the construction of joint-stock companies here. It means that there are enterprises and societies established mainly for the irrigation of fertile lands for cotton cultivation [3, p.175].

D.N. Logofet also carried out important work in the study of archeological monuments of the Surkhandarya oasis [8, p.85]. He sees small castles from Samarkand in the Surkhandarya oasis near the Darband post and mentions several other fragments of pottery (8, p.152157]. He also gives information about the Budrachtepa archeological finds north of Termez [8, p.169]. During his travels along the Bukhara-Afghan border, DN Logofet also gave information about the Takhtikubod post [9, p.1909].The tourist also spoke about the activities of the Amudarya Flotilla, noting that the Termez and Kerki garrisons played an important role in the wheat trade of Boljuvan, Kulob and Kurgan-Tube principalities with Afghanistan [10, p.116]. 


\section{CONCLUSION}

In conclusion, in the study of the history of the Surkhandarya oasis, the study of the activities and works of Russian researchers, orientalists, especially D.N. Logofet, is of great importance.

\section{REFERENCES}

1. Soloviev V.S, "D.N Logofet-researcher of Eastern Bukhara" // History: facts and symbols. -2015. Issue 3 (No. 4) .- P.67-74.

2. Logofet D.N. Land of lawlessness. Petersburg, 1909 .-- p. 16.

3. Turkestan collection-T.497- p.109-110

4. Kabulov E. Place of the Surkhan valley in trade relations between Russia and the Eastern countries // Universum: Social sciences. - 20156 No. 1-2. - P.2-3.

5. Logofet D.N. Bukhara Khanate under Russian protectorate. T.2. - SPb, 1911.

6. Kabulov E. Russian Empire works on improving the Surhan oasis irrigation system // Bulletin of Science and Practice. No. 11, 2016. - P.344

7. Turkestan collection-T .. 417.- p. 105.

8. Logofet D.N. In the mountains and plains of Bukhara. - SPb., 1913

9. Logofet D.N. On the borders of Central Asia. Book. III: Bukhara-Afghan border. - SPb., 1909.

10. Turkestan collection-T., 442-p.114-11610. 